\title{
Nursing diagnoses and interventions for a child after cardiac surgery in an intensive care unit
}

\author{
Diagnósticos e intervenções de enfermagem para uma criança pós-cirurgia cardíaca em \\ unidade de terapia intensiva \\ Diagnósticos y intervenciones de enfermería para una niña en el postoperatorio de cirugía \\ cardiaca en unidad de cuidados intensivos
}

\begin{abstract}
Agueda Maria Ruiz Zimmer Cavalcante', Evelise Helena Fadini Reis Brunori', Camila Takáo Lopes", Andréa Braz Vendramini Silva', T. Heather Herdman"'I

'Instituto Dante Pazzanese de Cardiologia. São Paulo-SP, Brasil.

"Hospital Universitário, Unidade de Terapia Intensiva Adulto. São Paulo-SP, Brasil.

II' University of Wisconsin-Green Bay. Green Bay-WI, United State of America.
\end{abstract}

Submissão: 05-12-2014 Aprovação: 09-12-2014

\section{ABSTRACT}

Objective: to describe the nursing clinical judgment as a basis for ND identification and development of a NIC treatment plan for a child after cardiac surgery under intensive care. Method: a case study with data retrospectively collected from charts. Results: Three nurses identified NANDA-I diagnoses and NIC interventions. A 6-month-old child submitted to cardiac surgery, requiring extracorporeal membrane oxygenation in the postoperative period. Four main nursing diagnoses were identified, towards which ten interventions were directed. The proposal of interventions to respond to the priority human responses of the child was optimized by the use of standard terminologies. Every nursing diagnosis was supported by diagnostic indicators; every intervention was scientifically supported. Conclusion: there must be an expectation that nurses address not only physiological responses, but also those within psychosocial domains.

Key words: Nursing Diagnosis; Nursing Care; Controlled Vocabulary; Child; Thoracic Surgery.

\section{RESUMO}

Objetivo: descrever o julgamento clínico de enfermagem para identificar diagnósticos NANDA e desenvolver um plano de tratamento NIC para uma criança em pós-operatório de cirurgia cardíaca em terapia intensiva. Método: estudo de caso com coleta de dados retrospectiva no prontuário. Resultados: três enfermeiras identificaram diagnósticos NANDA e intervenções NIC. Criança de 6 meses, submetida a cirurgia cardíaca, necessitou oxigenação extracorpórea por membrana no pós-operatório. Foram identificados quatro principais diagnósticos, aos quais foram direcionadas dez intervenções. A proposta de intervenções para responder às necessidades humanas prioritárias da criança foi otimizada pelo uso das terminologias padronizadas. Todos os diagnósticos foram sustentados por indicadores diagnósticos; todas as intervenções foram cientificamente sustentadas. Conclusão: espera-se que os enfermeiros abordem não somente as respostas fisiológicas, mas também aquelas dos domínios psicossociais.

Descritores: Diagnóstico de Enfermagem; Cuidados de Enfermagem; Vocabulário controlado; Criança; Cirurgia Torácica.

\section{RESUMEN}

Objetivo: describir el raciocinio clínico de enfermería para identificar diagnósticos y planear intervenciones NIC para una niña en el postoperatorio de cirugía cardíaca. Método: estudio de caso con datos recogidos de forma retrospectiva en registros. Resultados: tres enfermeras propusieron diagnósticos NANDA-I e intervenciones NIC. Niña de 6 meses de edad, sometida a cirugía cardíaca requirió oxigenación por membrana extracorpórea en el postoperatorio. Cuatro principales diagnósticos fueron identificados para los cuales diez intervenciones de enfermería fueron direccionadas. La propuesta de intervenciones para las respuestas humanas prioritarias de la niña fue optimizada por el uso de terminologías estándar. Todos los diagnósticos fueron apoyados por indicadores, cada intervención apoyada científicamente. Conclusión: los enfermeros deben abordar no sólo las respuestas fisiológicas, sino también los dominios psicosociales.

Palabras clave: Diagnóstico de Enfermería; Atención de Enfermería; Vocabulario Controlado; Niño; Cirurgía Torácica.

\section{AUTOR CORRESPONDENTE}

Agueda Maria Ruiz Zimmer Cavalcante

E-mail: enf_agueda@yahoo.com.br 


\section{INTRODUCTION}

High quality nursing care for children in cardiac intensive care units (ICU) demands professional nursing knowledge and practical skills, due to its specificity and complexity. Nurses must be knowledgeable about the human responses of these children; many of their responses are physiological, yet there are a multitude of psychosocial, behavioral and family responses that are also very important for the nurse to understand, diagnose and treat.

A thorough nursing assessment to identify signs and symptoms provides data critical to identifying nursing-sensitive human responses, and their etiologies; these are the clinical indicators of nursing diagnoses (ND) as approved by NANDA International, Inc. (NANDA-I). Nursing diagnoses represent clinical nursing inferences and drive the identification and implementation of treatment plans for these patients during their hospitalization.

Standardized nursing terminologies can support clinical reasoning and decision-making processes used for quality patient care. Therefore, we describe the nursing clinical judgment as a basis for ND identification and development of a NIC treatment plan for a child after cardiac surgery under intensive care.

\section{METHODS}

A case study with data collection from medical/nursing records of a child in an ICU of a public cardiology referral hospital in São Paulo, Brazil, on the first post-operative day. Nursing diagnoses from NANDA-( ${ }^{(1)}$ and interventions, using $\mathrm{NIC}^{(2)}$, were then proposed by three nurses with at least one year of experience in pediatrics. Two were cardiology nurse specialists and one was an ICU nurse specialist, two with a master's degree; all were familiar with the referenced nursing terminologies. Similar to a previous case report $^{(3)}$, and despite the fact that nursing should view the patient and family in a holistic manner, the results of this case study were based entirely on the physiological responses of the child. This was not the desired outcome; unfortunately, information related to psychological, behavioral, social, and family factors were not described in the medical or nursing records.

\section{RESULTS}

A $5.8 \mathrm{~kg}$ white female, six months of age, was admitted in 2012 with a history of shortness of breath since birth. The chest x-ray showed an increased cardiac area $(3+/ 4+)$ and the transthoracic echocardiogram (TTE) showed total anomalous pulmonary venous drainage (TAPVD), interatrial communication (IAC), moderate tricuspid insufficiency and pulmonary hypertension $(\mathrm{PH})$. Correction of the TAPVD and IAC occlusion was performed. Cannulation of the aorta and superior vena cava was used for extracorporeal membrane oxygenation (ECMO), which was maintained postoperatively due to decreased cardiac output and $\mathrm{PH}$; inhaled nitric oxide (INO) associated with mechanical ventilation (MV) was also used.

Postoperatively, the child's chest remained open with the sternotomy wound covered with a membrane. She had a nasogastric tube, bilateral chest tubes, an arterial catheter, a central venous catheter and a Foley catheter. The child was maintained at nil per os (NPO) status, with enteral nutrition maintaining capillary glycemia of $141-317 \mathrm{mg} / \mathrm{dL}$. Chest tube drainage was significant $(3.9 \mathrm{ml} / \mathrm{kg} / \mathrm{h})$. Vital sign variation noted was: temperature: $34.5-$ $38.3^{\circ} \mathrm{C}$; heart rate: $93-177 \mathrm{bpm}$; MAP: $42-119 \mathrm{mmHg}$; respiratory rate: $28-50 \mathrm{rpm}$; oxygen saturation: $80-99 \%$. Laboratory values included: platelets $37,000 / \mathrm{ml}$; prothrombin time 23.6 seconds; activated partial thromboplastin time 34.7 seconds; INR 1.9.

In the immediate postoperative period, the child was pale, continuously sedated, non-responsive to stimuli, intubated with mechanical ventilation enabling good lung expansion; vesicular murmurs and rales were present. The child was hemodynamically unstable and required continuous infusion of milrinone and adrenaline or noradrenaline. She exhibited $3+/ 4+$ generalized edema, pulses were palpable, capillary reperfusion time of 3 to 4 seconds hypophonetic cardiac sounds due to significant pericardial effusion with signs of cardiac tamponade as shown by TTE. The pericardial effusion was drained with immediate improvement of the mean arterial pressure (MAP) (46 to $65 \mathrm{mmHg}$ ). The liver edge was palpable at about $3 \mathrm{~cm}$ below the right costal margin midclavicularly. Fluid balance/24 hour period was positive; urine was hematuric. Dialysis was initiated, using the extracorporeal membrane oxygenation (ECMO) device. Arterial blood gas (ABG) results were: $\mathrm{pH}$ 7.04-7.3; $\mathrm{pO}_{2}$ 37.9-39.1; $\mathrm{pCO}_{2}$ 60.9; $\mathrm{HCO}_{3}$ 19.9-22.5; $\mathrm{BE}-10$ - 9.1.

In order to understand much of the data that the nurse must assess, cluster together and use as a basis for diagnosis, it is necessary to understand the pathophysiology of this particular child's case. One of the CHD that may require ECMO and INO is TAPVD, in which all pulmonary veins abnormally drain to the right atrium, dilating those chambers, while the left heart chambers are reduced. This overflow leads to $\mathrm{PH}$ and symptoms such as dyspnea, sweating, tachycardia, heart failure, respiratory infections and mild cyanosis. Early surgical intervention is mandatory, and mortality rate in the first year is approximately 80 to $90 \%{ }^{(4)}$. Inhaled nitrous oxide has been studied in the context of cardiac surgery for congenital heart disease (CHD). It acts as a selective pulmonary vasodilator by binding to oxygen-saturated hemoglobin, which leads to the formation of nitrate and methemoglobin and thereby prevents systemic vasodilation. Exclusive pulmonary vasodilation maximizes ventilation ${ }^{(5)}$. The ECMO procedure removes blood, oxygenates it through an artificial lung, and returns it to the aorta to treat those with severe heart and respiratory failure ${ }^{(6)}$.

The NANDA-I diagnostic criteria provide a "quality check" to ensure accuracy in diagnosis; without identified clinical evidence or defining characteristics (signs/symptoms) and related (etiologic) factors, it is impossible to know if diagnoses are accurate for a particular patient. Additionally, the definition of the diagnosis label provides the nurse with the ability to clarify that her clinical judgment is truly represented by the identified diagnosis. Inaccurate diagnosis can lead to ineffective and inefficient intervention, and can jeopardize patient safety and outcomes.

Priority NDs for this case study were consensually identified based on documented information available in the child record. The NIC interventions were proposed, based on literature-based support for their use in individuals with similar human responses (Board 1). 
Board 1 - Nursing diagnoses and interventions for a child with congenital heart disease in the postoperative period

\begin{tabular}{|c|c|c|}
\hline $\begin{array}{l}\text { Nursing } \\
\text { diagnosis }\end{array}$ & \multicolumn{2}{|c|}{$\begin{array}{l}\text { Decreased cardiac output (00029) related to altered afterload, altered contractility and altered stroke volume, as } \\
\text { evidenced by: clammy skin, crackles, decreased peripheral pulses, decreased systemic vascular resistance, edema, } \\
\text { increased pulmonary vascular resistance, oliguria, prolonged capillary refill, skin color changes }\end{array}$} \\
\hline $\begin{array}{l}\text { Nursing } \\
\text { interventions }\end{array}$ & \multicolumn{2}{|l|}{$\begin{array}{l}\text { Shock management: cardiac (4254); } \\
\text { Circulatory care: mechanical assist device (4064) } \\
\text { Hemodynamic regulation (4150) }\end{array}$} \\
\hline $\begin{array}{l}\text { Nursing } \\
\text { activities }\end{array}$ & $\begin{array}{l}\text { Note signs and symptoms of decreased output } \\
\text { Auscultate lung sounds for crackles or other } \\
\text { adventitious sounds } \\
\text { Perform a comprehensive appraisal of peripheral } \\
\text { circulation (e.g., check peripheral pulses, edemas, } \\
\text { capillary refill, color, and extreme temperature) } \\
\text { Monitor sensory and cognitive capacities } \\
\text { Evaluate pulmonary artery pressures, systemic } \\
\text { pressures, cardiac output, and systemic vascular } \\
\text { resistance, as indicated } \\
\text { Monitor the device regularly to ensure proper } \\
\text { functioning } \\
\text { Observe cannulas for kinks or disconnection } \\
\text { Determine activated clotting times every hour, as } \\
\text { appropriate } \\
\text { Administer positive inotropic/contractility medications } \\
\text { Maintain fluid balance by administering IV fluids or } \\
\text { diuretics, as appropriate } \\
\text { Evaluate side effects of negative inotropic medications } \\
\text { Use strict aseptic technique in changing dressings } \\
\text { Monitor electrolytes, BUN, and creatinine daily }\end{array}$ & $\begin{array}{l}\text { Monitor weight daily } \\
\text { Obtain chest X-ray daily } \\
\text { Monitor for fever and leukocytosis } \\
\text { Monitor and document heart rate rhythm, and pulses } \\
\text { Evaluate effects of fluid therapy } \\
\text { Provide emotional support for the patient and family } \\
\text { Monitor coagulation profiles every } 6 \text { hr, as appropriate } \\
\text { Administer anticoagulants or antithrombolytics, as } \\
\text { ordered } \\
\text { Observe for hemolysis as indicated by blood in the } \\
\text { urine, hemolyzed blood specimens, increase in daily } \\
\text { serum hemoglobin, frank bleeding, and hyperkalemia } \\
\text { Monitor intake and output } \\
\text { Monitor urine output every hour } \\
\text { Monitor electrolyte levels } \\
\text { Recognize presence of blood pressure alterations } \\
\text { Minimize/eliminate environmental stressors }\end{array}$ \\
\hline $\begin{array}{l}\text { Nursing } \\
\text { diagnosis }\end{array}$ & \multicolumn{2}{|c|}{ Risk for bleeding (00206) evidenced by treatment-related side effects (cardiac surgery, ECMO, hemodilution) } \\
\hline $\begin{array}{l}\text { Nursing } \\
\text { interventions }\end{array}$ & \multicolumn{2}{|l|}{$\begin{array}{l}\text { Bleeding precautions (code 4010) } \\
\text { Bleeding reduction (code 4020) }\end{array}$} \\
\hline $\begin{array}{l}\text { Nursing } \\
\text { activities }\end{array}$ & $\begin{array}{l}\text { Monitor the patient closely for hemorrhage } \\
\text { Note hemoglobin/hematocrit levels before and after } \\
\text { blood loss, as indicated } \\
\text { Monitor coagulation studies, including prothrombin } \\
\text { time (PT), partial thromboplastin time (PTT), } \\
\text { fibrinogen, fibrin degradation/split products, and } \\
\text { platelets counts, as appropriate } \\
\text { Monitor for signs and symptoms of persistent bleeding } \\
\text { (e.g.; check all secretions for frank or occult blood) } \\
\text { Perform proper precautions in handling blood } \\
\text { products or bloody secretions } \\
\text { Avoid injections (IV, IM or SC), as appropriate }\end{array}$ & $\begin{array}{l}\text { Maintain patent IV access } \\
\text { Administer blood products (e.g., platelets and fresh } \\
\text { frozen plasma), as appropriate } \\
\text { Monitor trends in blood pressure and hemodynamic } \\
\text { parameters, if available (e.g., central venous pressure } \\
\text { and pulmonary capillary/artery wedge pressure) } \\
\text { Monitor determinants of tissue oxygen delivery (e.g., } \\
\mathrm{PaO}_{2}, \mathrm{SaO}{ }_{2} \text {, and hemoglobin levels and cardiac output), } \\
\text { if available } \\
\text { Monitor the amount and nature of blood loss } \\
\text { Refrain from inserting objects into a bleeding orifice }\end{array}$ \\
\hline $\begin{array}{l}\text { Nursing } \\
\text { diagnosis }\end{array}$ & \multicolumn{2}{|c|}{$\begin{array}{l}\text { Impaired spontaneous ventilation (00033) related to metabolic factors (increased metabolic rate, metabolic } \\
\text { acidosis) as evidenced by: decreased } \mathrm{pO}_{2} \text {, } \frac{\text { decreased } \mathrm{SaO}_{2} \text { and increased } \mathrm{pCO}_{2}}{}\end{array}$} \\
\hline $\begin{array}{l}\text { Nursing } \\
\text { interventions }\end{array}$ & \multicolumn{2}{|l|}{$\begin{array}{l}\text { Respiratory monitoring (code 3350) } \\
\text { Mechanical Ventilation management: invasive (code 3300) }\end{array}$} \\
\hline $\begin{array}{l}\text { Nursing } \\
\text { activities }\end{array}$ & $\begin{array}{l}\text { Monitor rate, rhythm, depth, and effort of respirations } \\
\text { Note chest movement, watching for symmetry, use of } \\
\text { accessory muscles, and supraclavicular and intercostal } \\
\text { muscle retractions } \\
\text { Monitor chest x-ray reports } \\
\text { Routinely monitor ventilator settings } \\
\text { Monitor the effectiveness of MVon patient's } \\
\text { physiological and psychological status } \\
\text { Monitor for adverse effects of mechanical ventilation: } \\
\text { infection, barotrauma, reduced cardiac output } \\
\text { Check all ventilator connections regulary }\end{array}$ & $\begin{array}{l}\text { Monitor patient's respiratory secretions } \\
\text { Determine the need for suctioning by auscultating for } \\
\text { crackles and bronchi over major airways } \\
\text { Monitor for respiratory muscle fatigue } \\
\text { Ensure that ventilator alarms are on } \\
\text { Monitor effects of ventilator changes on oxygenation: } \\
\mathrm{ABG}^{\mathrm{S} S \mathrm{SaO}} \mathrm{SvO}_{2^{\prime}} \text { end-tidal } \mathrm{CO}_{2}, \mathrm{Qsp} / \mathrm{Qt}, \mathrm{A}^{-} \mathrm{aDO}_{2^{\prime}} \\
\text { patient's subjective response } \\
\text { Monitor for decrease in exhaled volume and increase } \\
\text { in inspiratory pressure } \\
\text { Provide routine oral care }\end{array}$ \\
\hline
\end{tabular}




\begin{tabular}{|c|l|l|}
\hline $\begin{array}{c}\text { Nursing } \\
\text { diagnosis }\end{array}$ & $\begin{array}{l}\text { Risk for infection (00004) evidenced by inadequate primary defenses (immature immune system, broken skin/ } \\
\text { open surgical wound and altered peristalsis), inadequate secondary defenses (decreased hemoglobin), increased } \\
\text { environmental exposure to pathogens, multiple invasive procedures }\end{array}$ \\
\hline $\begin{array}{c}\text { Nursing } \\
\text { interventions }\end{array}$ & $\begin{array}{l}\text { Infection control (6540) } \\
\text { Infection protection (6550) }\end{array}$ & $\begin{array}{l}\text { Ensure aseptic handling of all IV lines } \\
\text { Obtain cultures, as needed } \\
\text { Monitor absolute granulocyte count, WBC count, and } \\
\text { differential results }\end{array}$ \\
\hline $\begin{array}{l}\text { Nursing } \\
\text { activities }\end{array}$ & $\begin{array}{l}\text { Do the observance of universal precautions } \\
\text { Ensure appropriate wound care technique } \\
\text { Monitor for systemic and localized signs and symptoms } \\
\text { of infection } \\
\text { Inspect condition of any surgical incision/wound }\end{array}$ & \multicolumn{2}{|l}{} \\
\hline
\end{tabular}

\section{DISCUSSION}

In the present study, the nurses arrived through consensus at a prioritization of four ND based on data available in the charts: decreased cardiac output, risk for bleeding, impaired spontaneous ventilation, and risk for infection. Based on these ND and their etiologies, evidence-based NIC interventions for the child's care were then selected.

Decreased cardiac output is defined by NANDA-I as: "inadequate blood pumped by the heart to meet the metabolic deman$\mathrm{ds}$ of the body ${ }^{\prime \prime(1)}$. Nine defining characteristics (DC) were identified during the child's assessment related to altered contractilty, afterload and stroke volume. The DC and related factors identified in our case study were similar to those found in another study ${ }^{(7)}$. Four main factors influence the severity of the decreased cardiac output in children: age lower than one month, weight lower than $2.5 \mathrm{~kg}$, the preoperative condition of the patient, and the disease complexity ${ }^{(8)}$. In this case, the child presented severe disease, with increased cardiac area, $\mathrm{PH}$ and altered breathing pattern caused by transposition of the great vessels.

Circulatory care: mechanical assist device (code 4064) is defined by NIC as "temporary support of the circulation through the use of mechanical devices or pumps ${ }^{\prime \prime 2}$. When caring for children requiring $\mathrm{INO}$ and $\mathrm{ECMO}$, it is essential that nurses understand important signs of complications in order to safely monitor the patient and her response. Shock management: cardiac (code 4254) is defined as "promotion of adequate tissue perfusion for a patient with severely compromised pumping function of the heart" ${ }^{\prime \prime 2}$. In postoperative cardiac surgery care for children, assessment of the temperature of the lower limbs has been used as a measurement of peripheral perfusion. The difference between this measurement and core temperature can still be considered a predictor of postoperative mortality ${ }^{(8)}$. Finally, hemodynamic regulation (code 4150) is the, "optimization of heart rate, preload, afterload, and contractility"(2). Hemodynamic monitoring plays a key role in the assessment of children with $\mathrm{CHD}$, aiming at early detection of imbalance between oxygen supply and demand, which can impact survival, risk stratification and estimate prognosis. The parameters used in hemodynamic monitoring in cardiac surgery include EKG, invasive blood pressure, central venous pressure, pulse oxymetry and capnography. Continuous monitoring of pulmonary artery pressure has proven crucial in postoperative management of TAPV ${ }^{(8)}$.

Surveillance, an important, proactive nursing role for addressing and preventing potential complications of patient care, requires constant monitoring and observation of the patient's health condition $^{(9-10)}$. Therefore, it is necessary to recognize abnormal patterns and to identify a worsening clinical picture in order to obtain necessary data to make decisions and intervene proactively.

The NANDA-I ND, risk for bleeding (code 00206), is defined as "at risk for a decrease in blood volume that may compromise health" ${ }^{\prime \prime 1}$. The surgical procedure and ECMO are both strongly related to bleeding in children. Neonates and small infants are the highest risk group for excessive bleeding after cardiac surgery ${ }^{(11)}$. Hemodilution, and the consequent decrease in platelets and coagulation factor, is the most important mechanism for the development of coagulopathy in this clinical situation, due to the large discrepancy in the child's blood volume and the priming volume of the bypass circuit ${ }^{(11)}$. Following surgical correction of $\mathrm{CHD}$ requiring $\mathrm{ECMO}$, bleeding occurs in $63 \%$ of pediatric patients ${ }^{(11)}$ mainly due to the need for surface heparinization of the system ${ }^{(12)}$.

Bleeding precautions (Code 4010) is a NIC defined as "reduction of stimuli that may induce bleeding or hemorrhage in at-risk patients"(2). Bleeding reduction (Code 4020) is defined as "limitation of the loss of blood volume during an episode of bleeding"(2). These interventions primarily include monitoring and observational activities, important components of surveillance: a mental process of sustained attention through which nurses can determine if and when the readiness to rescue the patient from bleeding has become a need for rescue $^{(10)}$. Although blood loss via chest tubes is expected after cardiac surgeries, the risk of excessive loss requires vigilance with regard to output, coagulation exams and vital signs in order to early detect the need for blood product transfusion as well as transfusion reactions ${ }^{(11)}$.

The NANDA-I ND, impaired spontaneous ventilation (00033), is defined as "decreased energy reserves resulting in an inability to maintain independent breathing that is adequate to support life" ${ }^{\prime \prime 1}$. Although no information was found in the literature on the prevalence of impaired spontaneous ventilation in pediatric ICU, it was identified as the third most prevalent diagnosis in an adult ICU ${ }^{(13)}$. Ventilatory support must be introduced early to improve oxygenation, decrease the risk of metabolic acidosis, and reduce oxygen consumption resulting from muscular effort. It must also be optimized so that the increased intrathoracic pressure does not decrease the venous return and cardiac output ${ }^{(14)}$.

After surgical correction of CHD, children with respiratory complications need prolonged mechanical ventilation, leading to longer length of stay. Pleural effusion, atelectasis, laryngitis, 
pneumomediastinum and pneumothorax are some of the more common respiratory complications in this population ${ }^{(16)}$.

Respiratory monitoring (Code 3350) is a NIC defined as "collection and analysis of patient data to ensure airway patency and adequate gas exchange" ${ }^{\prime \prime 2}$. Although oxygenation and ventilation are similar terms, their meanings are distinct. Ventilation refers to gas movement between the environment and the pulmonary alveoli; oxygenation refers to the current content of oxygen in the arterial blood, which is determined by adequate ventilation and perfusion of the pulmonary capillary ${ }^{(16)}$. Hemoglobin values are important as an assessment of patient's oxygenation. Furthermore, signs such as cyanosis, low venous oxygen saturation, rhythm, and respiratory sounds are indispensable for the assessment of this system, and can influence therapeutic decisions and the treatment plan ${ }^{(16)}$.

Mechanical ventilation management: invasive (Code 3300) is a NIC intervention defined as "assisting the patient receiving artificial breathing support through a device inserted into the trachea"(2). Ventilator management of children in most ICUs is often based on arterial blood gas readings, along with corresponding measurements of inspired oxygen concentration. However, adequate functioning requires assessment of thoracic expansion, pulmonary auscultation, and signals of respiratory effort (cyanosis, sudoresis, nasal flaring and increased respiratory frequency). Patency of the endotracheal tube must be assured through suctioning, as needed, which can be assessed through pulmonary auscultation ${ }^{(7)}$.

The NANDA-I ND, risk for infection (Code 00004) is defined as "at risk for being invaded by pathogenic organisms"(1). This patient's open wound and multiple invasive procedures indicated the appropriateness of this diagnosis. Bloodstream and surgical wound infections in the postoperative period of pediatric cardiac surgery exacerbate the symptoms of ineffective breathing pattern, increase length of stay, morbidity, and mortality ${ }^{(16,9)}$. Nursing interventions related to this diagnosis must therefore focus on epidemiological vigilance, i.e., surgical wound monitoring, early identification of signs and symptoms, reviewing laboratory exams, and use of aseptic and/or sterile techniques for procedures to prevent infections ${ }^{(5)}$.

Infection control (Code 6540) is a NIC defined as "minimizing the acquisition and transmission of infectious agents"(2). The NIC, infection protection (Code 6550), is defined as "prevention and early detection of infection in a patient at risk" ${ }^{\prime \prime 2)}$. Among 6,314 patients with CHD after cardiac surgeries, aged 1 to 18 years, 197 had postoperative infections. Out of these, three had more than one type of infection and the mortality rate was $25.38 \%$ compared with $3.91 \%$ in patients without infections ${ }^{(17)}$. Moreover, children are susceptible to infections due to immaturity of their immune system. Additionally, procedures, such as mechanical ventilation, ECMO and venous access minimize the protective barriers and making the children more vulnerable to infectious processes. Therefore, permanent actions that can prevent or minimize infections must be ensured during hospitalization ${ }^{(18)}$.

Of substantial concern was the lack of assessment data available related to the NANDA-I ND, acute pain (code 00132)(1), of the child or a focus on its management. In patients who are not able to communicate due to age, sedation, or other causes, nurses must rely on objective measurements of pain (e.g., respiratory rate and oxygenation changes, body positioning or movement, facial changes $)^{(15)}$. A recent study on pain in infants undergoing cardiac surgery ${ }^{(19)}$ identified a reduction in systemic systolic blood pressure and a rise in pulmonary artery pressure during painful stimulation on the first post-operative day. It is therefore critical that pain assessment and pain management should be of primary importance in postoperative cardiac infants.

Likewise, information was unavailable in the patient record that could have provided relevant cues to social, environmental or knowledge-related concerns or strengths that could impact this patient positively or negatively in the intraoperative and post-discharge periods. Although one might expect to see fear, anxiety, parental/caregiver role strain, and other possible diagnoses for this family, it is impossible for us to diagnose what was not assessed. Nurses must not forget, within ICU environments, the importance of holistic assessment and diagnosis related to patients and their families, to improve outcomes and prevent post-discharge complications.

\section{CONCLUSIONS}

The consensual proposal of interventions to respond to the priority human responses of the child in this case study was optimized by the use of standard terminologies. Every ND was supported by diagnostic indicators (defining characteristics and related factors); every intervention implemented was scientifically supported. Further studies are needed to assess the efficacy of nursing interventions, by use of nursing outcome indicators. Additionally, there must be an expectation that nurses address not only physiological responses, but those within the coping/ stress tolerance, role-relationship, health promotion, life principles, comfort and growth/development domains, as well.

The use of NANDA-I and NIC standardized terminologies incorporates a consistent method based on scientific theory and evidence, while promoting the visibility of nursing knowledge and clinical judgment leading to appropriate nursing intervention. The use of these terminologies and understanding of the concepts and theories that underpin the ND is critical for quality care of these patients and their families.

\section{REFERENCES}

1. NANDA International. Nursing diagnoses: definitions and classification, 2012-2014. Oxford (GB): Wiley-Blackwell; 2012.
2. Bulechek G, Butcher H, Dochterman J, Wagner C, editores. Classificação das intervenções de enfermagem. Rio de Janeiro (RJ): Elsevier; 2010. 
3. Lopes JL, Meneguim S, Muniz CCS, Palomo JSH. Special Report: nursing diagnoses and interventions for a child with dilated cardiomyopathy requiring intra-aortic balIoon pump support - Case Report. Int J Nurs Terminol Classif. 2011;22(1):23-32.

4. Sadowski SL. Congenital Cardiac disease in the newborn infant: past, present, and future. Crit Care Nurs Clin North Am. 2009;21(1):37-48.

5. Checchia PA, Bronicki RA, Goldstein B. Review of inhaled nitric oxide in the pediatric cardiac surgery setting. Pediatr Cardiol. 2012;33(4):493-505.

6. Azevedo LCP, Park M, Costa ELV, Santo EV, Hirota A, Taniguchi $\mathrm{L}$, et al. Extracorporeal membrane oxygenation in severe hypoxemia: time for reappraisal? J Bras Pneumol. 2012;38(1):7-12.

7. Couchman BA, Wetzig SM, Coyer FM, Wheeler MK. Nursing care of the mechanically ventilated patient: what does the evidence say? Intensive Crit Care Nurs. 2007;23(1):4-14.

8. Atik FA. Hemodynamic monitoring in pediatric heart surgery. Arq Bras Cardiol. 2004;82(2):199-208.

9. Cavalcante AMRZ, Nakatani AYK, Bachion MM, Garcia TR, Nunes DP, Nunes PS. The analysis of activities not performed by the nursing team regarding the diagnosis of ineffective breathing pattern in the elderly. Rev Esc Enferm USP [Internet]. 2012 [cited 2013 November 16];46(3):604-11. Available from: http://www.scielo.br/scielo.php?script $=$ sci arttext\&pid $=$ S0080-62342012000300011\&lng $=$ en\&nrm $=\mathrm{iso} \& \operatorname{tlng}=\mathrm{en}$

10. Meyer GA, Lavin MA, Perry AG. Is it time for a new category of nursing diagnosis? Int J Nurs Terminol Classif. 2007; 18(2):45-50.

11. McEwan A. Aspects of bleeding after cardiac surgery in children. Paediatr Anesth. 2007;17(12):1126-33.

12. Dalton HJ, Butt WW. Extracorporeal life support: an update of Rogers' Textbook of Pediatric Intensive Care.
Pediatr Crit Care Med [Internet]. 2012 [cited 2013 November 16];13(4):461-71. Available from: http://www. ncbi.nlm.nih.gov/pubmed/22766541

13. Amante LN, Rossetto AP, Schneider DG. Nursing care systematization at the intensive care unit (ICU) based on Wanda Horta's theory. Rev Esc Enferm USP [Internet]. 2009 [cited 2013 November 16];43(1):54-64. Available from: http://www.scielo.br/scielo.php?script = sci_arttext \&pid $=$ S0080-62342009000100007

14. Karamlou T, Gurofsky R, Al Sukhni E, Coles JG, Williams WG, Caldarone CA, et al. Factors associated with mortality and reoperation in 377 children with total anomalous pulmonary venous connection. Circulation [Internet]. 2007 [cited 2013 November 16];115(12):1591-8. Available from: http://www.ncbi.nlm.nih.gov/pubmed/17353446

15. Herdman TH. Conceito do dor. In: NANDA Internacional, Herdman TH, Carvalho EC, Editores. PRONANDA: Programa de Atualização em Diagnóstico de Enfermagem. Porto Alegre (RS): Artmed Panamericana; 2013.

16. Becker DE, Casabianca AB. Respiratory monitoring: physiological and technical considerations. Anesth Prog [Internet]. 2009 [cited 2013 November 16];56(1):14-20. Available from: http://www.ncbi.nlm.nih.gov/pubmed/19562888

17. Kansy A, Jacobs JP, Pastuszko A, Mirkowicz-Małek M, Manowska $M$, Jezierska $E$, et al. Major infection after pediatric cardiac surgery: external validation of risk estimation model. Ann Thorac Surg [Internet]. 2012 [cited 2013 November 16];94(6):2091-5. Available from: http://www. ncbi.nlm.nih.gov/pubmed/23040826

18. Strunk T, Currie A, Richmond P, Simmer K, Burgner D. Innate immunity in human newborn infants: prematurity means more than immaturity. J Matern Fetal Neonatal Med. 2011;24(1):25-31.

19. Cury MRJ, Martinez FE, Carlotti APCP. Pain assessment in neonates and infants in the post-operative period following cardiac surgery. Postgrad Med J. 2013;89(1048):63-7. 